Review

\title{
Long non-coding RNAs associated with non-small cell lung cancer
}

\author{
Yuting Zhan ${ }^{1}$, Hongjing Zang ${ }^{1}$, Juan Feng ${ }^{1}$, Junmi Lu ${ }^{1}$, Lingjiao Chen ${ }^{1}$ and Songqing \\ Fan $^{1}$ \\ ${ }^{1}$ Department of Pathology, The Second Xiangya Hospital, Central South University, Changsha, Hunan, China
}

Correspondence to: Songqing Fan, email: songqingfan@csu.edu.cn

Keywords: NSCLC, InCRNAs, chemotherapy, radiotherapy, molecular therapy

Received: May 01, $2017 \quad$ Accepted: July 26, $2017 \quad$ Published: August 09, 2017

Copyright: Zhan et al. This is an open-access article distributed under the terms of the Creative Commons Attribution License 3.0 (CC BY 3.0), which permits unrestricted use, distribution, and reproduction in any medium, provided the original author and source are credited.

\begin{abstract}
Lung cancer, with $80-85 \%$ being non-small cell lung cancer (NSCLC), is the leading cause of cancer-related death in both men and women. Long non-coding RNAs (IncRNAs), always defined as non-protein-coding RNA molecules longer than 200 nucleotides, are now thought as a new frontier in the study of human malignant diseases including NSCLC. As researches continue, increasing number of roles that IncRNAs play in NSCLC has been found, and more and more evidences show IncRNAs have a close relationship with patients' response to radiochemotherapy or molecular therapy. The aim of this review is to disclose the roles that IncRNAs play in NSCLC and how IncRANs influence the treatment of NSCLC.
\end{abstract}

\section{INTRODUCTION}

Lung and bronchus cancer leads to most cancerrelated death, with an estimation about 85,920 and 72,160 death in men and women respectively in America, and it was also reported that there were totally 224,390 American people being diagnosed with lung and bronchus cancer in 2016 [1]. Looking around the world, greater than one-third of all newly diagnosed lung cancers occurred in China, resulting in a large social and economic burden. According to the annual report on the status of cancer in China, in total, 651,053 patients were newly diagnosed with lung cancer in 2011, including 441,364 men and 209,689 women [2]. Lung and bronchus cancer is usually classified into NSCLC and small cell lung cancer (SCLC) accounting for approximately $80 \%$ and $20 \%$ respectively, the former of which is traditionally treated with surgery combined with or without radiochemotherapy [3].

Long non-coding RNAs (lncRNAs), always defined as non-protein-coding RNA molecules longer than 200 nucleotides, are not thought as transcriptional "noise" any more, and have been regarded as a new frontier in the study of human malignant diseases such as brain, breast, prostate, liver, ovary, esophagus tumors and other kinds of diseases like Fragile X syndrome, Alzheimer's disease and etc $[4,5]$. LncRNAs, on the one hand, can regulate the expression of nearby protein-coding genes, and on the other hand, they themselves can serve key regulatory roles. In Jeremy's review, there are basically eight models for
lncRNAs to influence the gene expressions, and eventually play the biological roles [6]. As researches continue, it has been increasingly recognized that its dysregulations contribute to the development and progression of lung and bronchus cancer [7]. We conduct a comprehensive review of the published literatures focusing on the roles that $\operatorname{lncRNAs}$ play in the presence and development of NSCLC, retrospect the relationship between IncRNAs and radiochemotherapy as well as molecular targeted therapy of NSCLC, and discuss future directions about lncRNAs in the researches of NSCLC.

\section{Roles of LncRNAs in NSCLC}

It has been proved that the abnormal expression of IncRNAs has a close relationship to NSCLC. Here is a quick review of some popular and well-studied lncRNAs related to NSCLC.

\section{$M A L A T 1$ and NSCLC}

The metastasis-associated lung adenocarcinoma transcript 1 (MALAT1), also known as nuclear-enriched abundant transcript 2 (NEAT2), was firstly identified in 2003 by subtractive hybridization as prognostic parameters for patient survival in stage I of NSCLC. MALAT1, more than $8000 \mathrm{nt}$ expressed from chromosome 11q13, was detected not only in NSCLC, but also in some normal tissues such as pancreas, lung, prostate, ovary, colon, placenta, spleen, small intestine, kidney, heart, liver, testis 
and brain [8]. It was believed that MALAT1 expression levels were associated with patient survival by affecting genes involved in cancer like cellular growth, movement, proliferation, signaling, and immunoregulation [9]. Q-PCR was performed to confirm that the MALAT1 were upregulated in cancerous tissues than that in adjacent normal tissues [10]. And in vitro studies, migration and clonogenic growth could be suppressed by RNAinterference-mediated suppression of MALAT1 in A549 cells, while forced expression of MALAT1 in NIH 3 T3 cells significantly increased migration [9]. What's more, the level of MALAT1 was higher in brain metastasis and it was increased in highly invasive subline of brain metastasis lung cancer cells, which was speculated on account for epithelial-mesenchymal transition (EMT) [11]. For the mechanism, there is no final conclusion until now. Some scholars thought it was regulated by DNA methylation [12] and some suspected MALAT1 of contributing to NSCLC by upregulating the expression of $\mathrm{Bcl}-2$ and its interacting proteins [13]. Besides, it is reported that MALAT1 regulates alternative splicing (AS) of pre-mRNAs, which is a key step in the regulation and diversification of gene function, by controlling the levels of active serine/arginine (SR) proteins and the distributions to nuclear speckles [14]. Above all were recognized as modes of action for MALAT1: regulation of gene expression or alternative splicing [15].

\section{HOTAIR and NSCLC}

HOX antisense intergenic RNA (HOTAIR), a 2.2 kilobase noncoding RNA residing in the HOXC locus, was firstly identified in 2007. Rinn et al. proved in that paper that it might regulate gene expression in HOX loci in cis or trans; alternatively, it might be the act of antisense transcription in the HOXC locus [16]. And it was widely accepted that HOTAIR regulated gene expression by EZH2 (a subunit of PRC2), which led to histone $\mathrm{H} 3$ lysine 27 trimethylation of the HOXD locus, and it also could mediate chromosomal remodeling [17, 18]. In addition, it was confirmed that HOTAIR was highly expressed in both NSCLC samples and cell lines compared with adjacent tissues and it indicated a poor prognosis [19]. In the mechanism of how HOTAIR contributed to NSCLC, it was thought that HOTAIR might facilitate the tumor development but not the carcinogenesis of NSCLC [20]. In the meantime, some scholars found that HOTAIR modified the promoter of $p 53$ and enhanced histone H3 lysine 27 trimethylation, which showed a negative relationship between HOTAIR and p53 in NSCLC cells [21]. What's more, it was reported that HOTAIR can activate $\mathrm{Wnt} / \beta$-catenin signaling pathway in esophageal squamous cell carcinoma [22]. In addition, HOTAIR could involve in EMT, and also worked as competitive endogenous RNAs (ceRNAs) [23].

\section{HOTTIP and NSCLC}

HOXA distal transcript antisense RNA (HOTTIP) is an antisense non-coding transcript located at the distal end of HOXA gene cluster. It was regarded as key intermediates to transmit information from higher order chromosomal looping into chromatin modifications, and thus coordinated long range gene activation, which was associated with the WDR5/MLL complex to drive the H3 lysine 4 trimethylation and gene transcription [24, 25]. And it was identified as the most significantly up-regulated lncRNAs in human primary hepatocellular carcinoma even in early stage [26]. In NSCLC, HOTTIP expression was higher than corresponding adjacent normal tissues and contributed to cell proliferation and migration, which was by regulating HOXA13 and functioning as oncogene [27].

Besides these relatively common and popular lncRNAs mentioned above, there were still some other lncRNAs proved having close relationship to NSCLC which will be presented in Table 1 and Table 2.

\section{LncRNAs associated with radiochemotherapy of NSCLC}

\section{LncRNAs and chemotherapy}

As is well-known, DNA damage repair (DDR) mechanisms, such as single-strand break, doublestrand break, bulky adducts, base mismatches and base alkylation, are playing important roles to maintain genomic stability. Thanks to these precise modulations, cells could maintain genomic integrity confronted with numerous physical or chemical or even deadly strikes [50-52]. Platinum, a kind of chemical elements, could also cause DNA damage, especially in tumor cells, where the DDR is not complete.

Since found by Rosenbery in 1969, platinum was widely used in clinical practice including chemotherapeutics of NSCLC, which benefited a lot of incipient or advanced patients [53, 54]. Tumor cells, which proliferated more rapidly than normal ones, could be influenced directly by anticarcinogen, thus stopping equal division of DNA to next generation [55]. Binding of platinum and genomic DNAs in cell nucleus was thought to play important roles in cancer therapy, which influenced transcription and DNA replication and finally led to death of tumor cells [56]. However, the use of platinum was limited due to its toxicity, drug resistance, and some other side effects, which was demonstrated closely to lncRNAs $[57,58]$. The polymorphisms of lncRNAs such as HOTTIP, CCAT2, H19, HOTAIR, MALATI, ANRIL and CASC8 were proved significantly associated with lung cancer risk or platinum-based chemotherapy response $[58,59]$. It was reported that HOTAIR was significantly upregulated in cisplatin-resistant NSCLC cells both in vitro and in vivo, and it could enhance tumor cell proliferation, influence G0/G1 cell-cycle arrest, and decrease tumor cell apoptosis. Further studies showed that overexpression of HOTAIR could promote tumor sphere formation, which upregulated 
Table 1: Overexpressed or upregulated IncRNAs in NSCLC tissues or cell lines and their functions and probable mechanism

\begin{tabular}{|c|c|c|c|}
\hline LncRNA & Function in NSCLC & probable mechanism & cition \\
\hline AGAP2-AS1 & $\begin{array}{l}\text { negatively correlated with poor prognostic } \\
\text { outcomes }\end{array}$ & $\begin{array}{l}\text { repressed tumor-suppressor LATS2 and } \\
\text { KLF2 transcription }\end{array}$ & [28] \\
\hline ATB & presented a lower survival probability & & {$[29]$} \\
\hline TCF7 & promoted invasion and self-renewal & $\begin{array}{l}\text { TCF7 upregulated EpCAM expression } \\
\text { through functioning as a competitive } \\
\text { endogenous RNA (ceRNA) }\end{array}$ & [30] \\
\hline SBF2-AS1 & increased the proliferation of NSCLC cells & negatively regulated $\mathrm{P} 21$ & {$[31]$} \\
\hline FOXD2-AS1 & $\begin{array}{l}\text { promoted NSCLC cell growth and NSCLC tumor } \\
\text { progression }\end{array}$ & Wnt/ $\beta$-catenin signaling & {$[32]$} \\
\hline HOXA11-AS & promoted development and progression of NSCLC & $\begin{array}{l}\text { regulated the expression of various } \\
\text { pathways and genes, especially DOCK } 8 \\
\text { and TGF-beta pathway. }\end{array}$ & [33] \\
\hline PCAT-1 & played an oncogenic role in NSCLC progression & & {$[34]$} \\
\hline BCAR4 & $\begin{array}{l}\text { associated with poorer } 5 \text {-year overall survival rate } \\
\text { of NSCLC patients }\end{array}$ & & {$[35]$} \\
\hline CCAT2 & promoted tumorigenesis & over-expression of Pokemon & {$[36]$} \\
\hline 00511 & functioned as an oncogene & $\begin{array}{l}\text { acted as a modular scaffold of EZH2/ } \\
\text { PRC } 2 \text { complexes }\end{array}$ & [37] \\
\hline XIST & $\begin{array}{l}\text { associated with shorter survival and poorer } \\
\text { prognosis }\end{array}$ & $\begin{array}{l}\text { by epigenetically repressing KLF2 } \\
\text { expression }\end{array}$ & {$[38]$} \\
\hline NEAT1 & correlated with poor prognosis & inhibition of miR-377-3p/ E2F3 axis. & [39] \\
\hline ANRIL & $\begin{array}{l}\text { correlated with advanced tumor-node-metastasis } \\
\text { stage and greater tumor diameter }\end{array}$ & & {$[40]$} \\
\hline ZFAS1 & $\begin{array}{l}\text { an independent prognostic factor for poor survival } \\
\text { of NSCLC patients }\end{array}$ & & {$[41]$} \\
\hline SNHG1 & associated with a poor overall survival & $\begin{array}{l}\text { inhibited miR-101-3p and activated of } \\
\text { Wnt/ } \beta \text {-catenin signaling pathway }\end{array}$ & {$[42]$} \\
\hline RGMB-AS1 & $\begin{array}{l}\text { correlated with differentiation, TNM stage, and } \\
\text { lymph node metastasis }\end{array}$ & $\begin{array}{l}\text { by regulating } \mathrm{RGMB} \text { expression though } \\
\text { exon } 2 \text { of } \mathrm{RGMB}\end{array}$ & {$[43]$} \\
\hline
\end{tabular}

expression of the tumor stem cell-related biomarkers such as Nanog, Oct3/4, Sox2, c-Myc, $\beta$-catenin, and Klf4 $[60,61]$. It was found inverse correlation between HOTAIR and $p 21$ [62], the latter of which was proved as a negative regulator of the cell cycle [63]. What's more, lncRNA $H 19$ had a negative relationship with cisplatinbased chemotherapy response, the enhancement of which associated with metastasis, induction of G0/G1 cellcycle arrest, cell proliferation, and increased apoptosis [64]. Other IncRNAs were reported to relate to response to chemotherapy such as HOTTIP in osteosarcoma [65],
MALAT1 in laryngeal squamous cell carcinoma [66], and $A N R I L$ in nasopharyngeal carcinoma [67].

\section{LncRNAs and radiotherapy}

Radiotherapy is essential in most patients especially with advanced stage NSCLC, usually sequentially or simultaneously combined with surgery, chemotherapy and molecular therapy $[68,69]$. Radioactive rays could cause a series of physical, chemical and biological damages to both tumor cells and normal cells, of which doctors make use, to cure cancer by reducing radiological dose of normal 
Table 2: Lower expressed or downregulated IncRNAs in NSCLC tissues or cell lines and their functions and probable mechanism

\begin{tabular}{lll}
\hline LncRNA & Function in NSCLC & probable mechanism \\
\hline TUSC7 & $\begin{array}{l}\text { associated with worse overall } \\
\text { survival }\end{array}$ & \\
CASC2 & $\begin{array}{l}\text { independent predictor for overall } \\
\text { survival of NSCLC }\end{array}$ & \\
& $\begin{array}{l}\text { indicated a poor prognosis and } \\
\text { regulated cell proliferation }\end{array}$ & \\
GAS5 & $\begin{array}{l}\text { related to the proliferation of } \\
\text { NSCLC cells }\end{array}$ & $\begin{array}{l}\text { TUG1 RNA could bind to PRC2 in the promotor region } \\
\text { of CELF1 and negatively regulated CELF1 expressions }\end{array}$ \\
& inhibited the proliferation and & inhibited the activation of Wnt/ $\beta$-catenin pathway \\
AK126698 & migration & [46] \\
GAS5-AS1 & $\begin{array}{l}\text { regulated NSCLC cell migration } \\
\text { and invasion }\end{array}$ & through regulation of EMT \\
\hline
\end{tabular}

tissues and increasing that of tumor cells [70]. LncRNAs were proved to involve in the DNA damage response after radioactive rays, which might lead to the failure of radiotherapy [71]. However, the detailed mechanisms about lncRNA and resistance to radioterapy haven't been found, but it is certain that miRNAs do involve in the radioresistance of head and neck cancer [72]. And it is deserved to investigate whether there are some relationship between lncRNAs and radioresistance in NSCLC.

\section{LncRNAs associated with molecular targeted therapy of NSCLC}

Basically speaking, there are three kinds of targeted therapies for NSCLC so far, namely EGFR tyrosine kinase inhibitors (EGFR-TKIs), antiangiogenic agents and Programmed cell death protein 1 inhibitors, which brings hopes and prospects to patients suffering NSCLC.

\section{EGFR and LncRNAs}

Epidermal growth factor receptor (EGFR) superfamily has been regarded as a therapeutic target to NSCLC. It was firstly reported in 2004 that the mutations of patients who were sensitive to gefitinib were around the ATPbinding pocket of the tyrosine kinase domain, which were small, in-frame deletions or amino acid substitutions [73]. Adenocarcinomas from never smokers were easier to acquire this kind of gene mutation, which meant they were more sensible to gefitinib or erlotinib [74]. According to statistics from Ohashi K, patients whose metastatic tumors identified EGFR mutations were expected to live longer than 2 years [75]. Following the use of these drugs, most patients who were initially sensitive to EGFR TKIs eventually acquired inevitable resistance after long-term therapy. And the EGFR T790M secondary mutation, which substituted methionine for threonine at residue 790, was firstly reported only a year later after the discovery of EGFR-TKIs [76]. The EGFR T790M secondary mutation was identified from patients who were not sensitive to EGFR-TKIs up to $68 \%$. Besides, there were some other rare mutation such as D761Y, L747S, and T854A discovered in 2006, 2007, 2008 respectively [77-79]. In addition, mechanisms such as MET amplification, PTEN downregulation, CRKL amplification, High-level expression of HGF, FAS-NFkB activation, EMT, and transformation to small cell lung cancer, were also working in the EGFR-TKIs resistance [80].

Few papers mentioned the relationship between lncRNAs and EGFR mutations in NSCLC. Urothelial cancer-associated 1 (UCA1), a long non-coding RNA highly specific to Bladder transitional cell carcinoma (TCC), was proved to have a close relationship to colorectal, gastric, ovarian cancer and NSCLC [81, 82]. $U C A 1$ acted as an oncogenic role in NSCLC and it was proved that the expression of UCA1 in NSCLC samples was significantly higher compared with adjacent tissues partly through competitively 'sponging' miR-506-3p [83]. $U C A 1$ was also highly expressed in patients with acquired resistance to EGFR-TKIs, and further studies showed that it was related to non-T790M by activating AKT/mTOR pathway and EMT [84].

LncRNA BC087858 could stimulate acquired resistance to EGFR-TKIs in NSCLC and might contribute to a shorter progression-free survival (PFS) [85]. Further study showed that lncRNA BC087858 could induce nonT790M mutation acquired resistance to EGFR-TKIs by activating PI3K/AKT and MEK/ERK pathways and EMT via upregulating ZEB1 and Snail and eventually promoted cell invasion [86].

Not only single lncRNA could influence EGFRTKIs resistance, but also lncRNAs could interact each other to affect the sensitivity to targeted therapy. The over and lower expression of CASC9 and lncRNA 00277 
were respectively negative to sensitivity to gefitinib in PC9G2 cells, and taken together, it was reported that they contributed to NSCLC cells EGFR-TKI resistance through interacting with their co-expressed gene, namely $P c G s$, and affected different biological pathways [87] (Figure 1).

\section{PD-1, PDL-1 and LncRNAs}

The microenvironment of malignant cells were gaining highlight to the treatment of tumors and many labs were concentrating on finding ways to make immune cells kill cancer cells. T cells were the major cells to fight or kill malignant cells, and the activation of T cells was partly depending on immune checkpoints $[88,89]$. Programmed cell death protein 1 (PD-1) and programmed cell death protein ligand 1 (PDL-1) are two of key components of immune checkpoints. It was widely accepted that the engagement of PD-1 by PDL-1 could suppress immune responses and consequently led to immune evasion [90, 91]. Therefore the study of PD-1 and PDL-1 is now offering new important opportunities for the therapy of cancer.

PDL-1 expression of tumor was significantly associated with a shorter PFS [92], and for the researches of its receptor, namely PD-1, showed that cumulative response rates to anti-PD-1 antibody were $18 \%$ among NSCLC patients according to a clinical trial in America (14 of 76 patients), which provided a kind of new method to NSCLC treatment [93]. Some scholars suggested the combination of EGFR-TKIs and immune checkpoints inhibitors, but due to the toxicity of this kind of combination, it aroused a lot of controversy [94, 95].

Although many evidences showed that PD-1/ PDL-1 had a promising future to treat with NSCLC, we knew little about the regulation about expression of PD-1/PDL-1. Previous studies demonstrated that PD-1.5 $\mathrm{C} / \mathrm{T}$ significantly increased advanced NSCLC risk and potentially related to NSCLC susceptibility in Chinese Han population [96]. However, to our knowledge, there was no report about the relationship between PD-1/PDL-1 and lncRNAs in NSCLC, and only one paper was found to reveal that the co-expression of lncRNA AFAP1-AS1 and PD-1 predicted poor prognosis of nasopharyngeal carcinoma (NPC) [97]. At present, it was found that $p 53$ regulated PDL-1 via miR-34, which directly binded to the

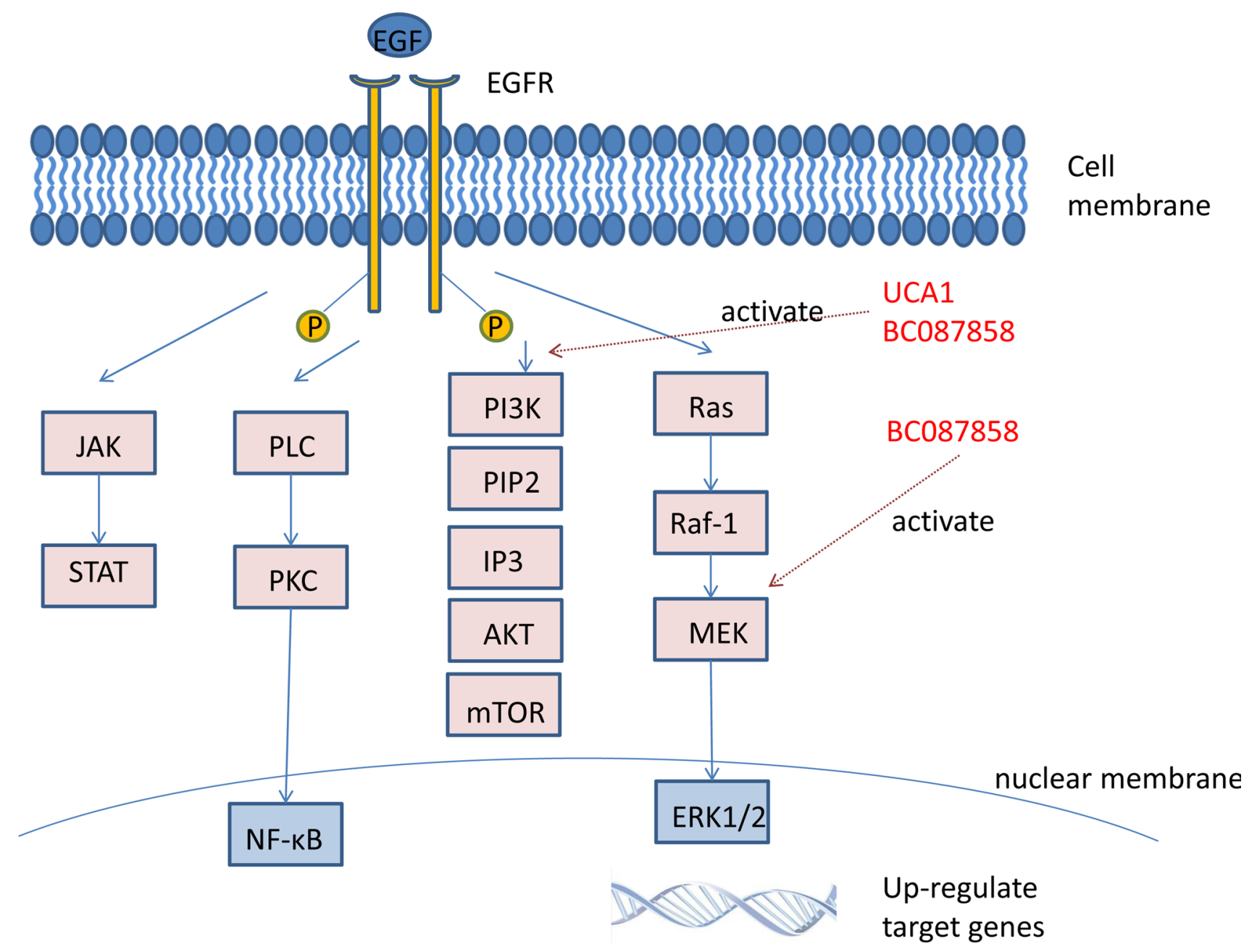

Figure 1: LncRNAs associated non-T790M mutation of NSCLC. UCA1 activated AKT/mTOR pathway and related to nonT790M mutation. LncRNA BC087858 induced non-T790M mutation by activating PI3K/AKT and MEK/ERK pathways. 
PDL-1 3'untranslated region in models of NSCLC [98]. What's more, it was also reported that miR-34 enhanced $\mathrm{T}$ cell activation via targeting diacylglycerol kinase $\zeta$ [99] (Figure 2A). Because the expression of miRNAs was quite specific to distinct tumors, and they could affect early regulation of immune responses, they were regarded as suitable molecules for cancer therapy [100]. In addition, lncRNAs could be precursors of miRNAs and act as ceRNAs to alter the distribution of miRNA molecules on their targets $[6,101]$ (Figure 2B), for example, it was found that lncRNA $A R S R$ acted as a ceRNA for miR-34 and miR-449 and finally promoted Sunitinib resistance in renal cancer [102]. Thereby we can speculate that IncRNAs probably influence the patients' response to antiPD-1 or anti-PDL-1 treatment.

\section{Antiangiogenic agents and LncRNAs}

Researches showed that tumor growth and metastatic potential partly related to tumor angiogenesis. Vascular endothelial growth factor (VEGF), inducing angiogenesis in vivo, was expressed in most solid cancers including NSCLC [103]. Bevacizumab, a humanized monoclonal antibody, could block the binding of VEGF-A isoforms to VEGF receptors and therefore against tumors [104]. The Food and Drug Administration approved bevacizumab for the treatment in first-line metastatic setting of colorectal cancer, non-small cell lung cancer and breast cancer, and randomized controlled trials (RCTs) showed that bevacizumab-based regimens revealed significantly increased overall survival (OS) $[105,106]$.

For the relationship between VEGF and lncRNAs, it was proved that $M A L A T 1$ could promote angiogenesis and immunosuppressive properties of mesenchymal stem cells by inducing VEFG in preeclampsia [107]. More direct evidence is that when lincRNA $p 21$ was inhibited, the expressions of angiogenesis-related genes were downregulated and lincRNA-p21-inhibited cells were observed to secrete less VEGFA than controls did [108].

\section{CONCLUSIONS AND FUTURE DIRECTIONS}

With the deep research, lncRNAs are not regarded as transcriptional "noise" any more, and they are thought to be a new frontier for many diseases including malignant tumors. Based on existing evidences, lncRNAs are playing important roles in the presence and development of NSCLC, which leads to most cancer-related death. What's more, over or lower expression of lncRNAs could alter the ability of cellular growth, movement, proliferation, signaling, immunoregulation and invasion, consequently to influence the prognostication of cancer. Besides, it has a close relationship between lncRNAs and the response to radiochemotherapy or molecular targeted therapy, by which ulteriorly affect the prognostication of NSCLC. Following the development of body fluid detection, lncRNAs test will not only be applied into operative tissues, but also in blood, urine and other body fluid and will have a better predictive and diagnostic function [109].

In the future, further studies would be concentrated on the following aspects: (1) identifying new lncRNAs (2) discovering more functions of lncRNAs (3) detecting more relationships with miRNAs and other non-coding RNAs (4) seeking more probable pathways that lncRNAs influence the gene transcript or protein expression (5) looking for possibility of lncRNAs as therapeutic targets (6) developing more precise and reliable ways to detect lncRNAs in body floods.
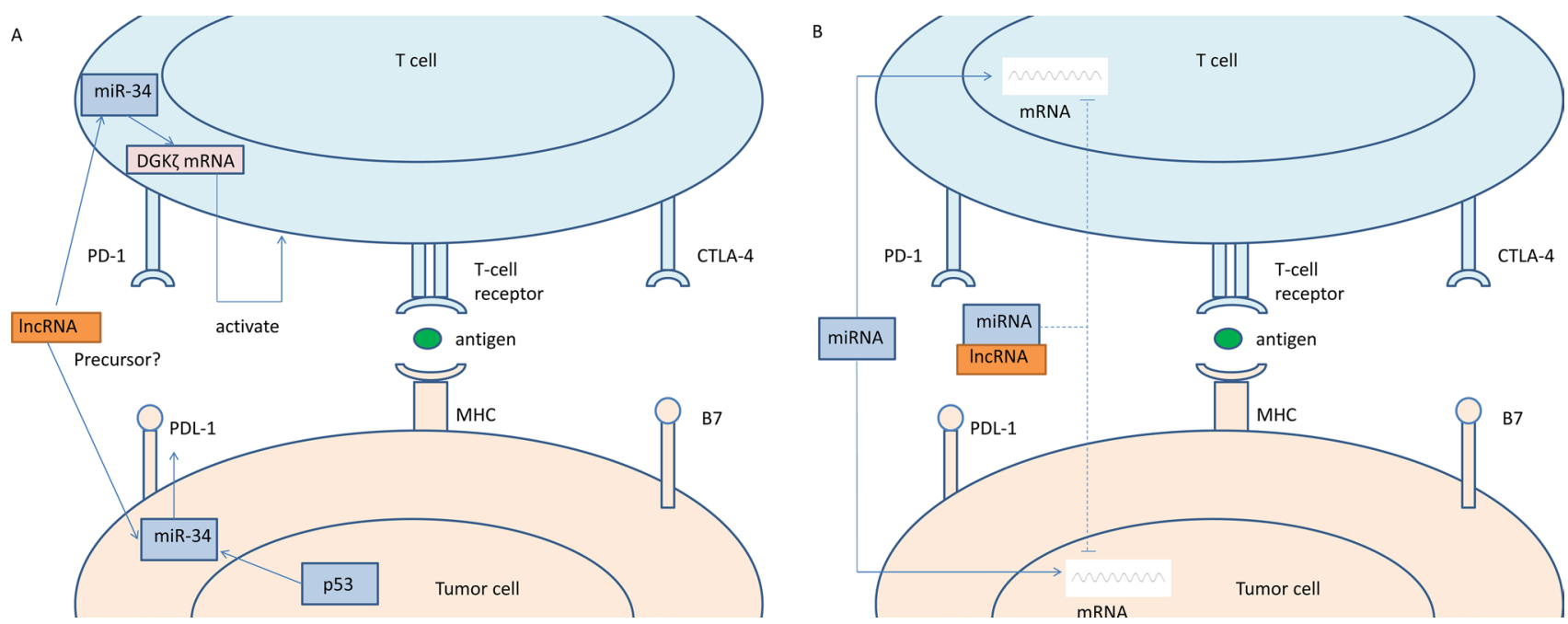

Figure 2: Hypothesis: LncRNAs associated the patients' response to anti-PD-1 or anti-PDL-1 treatment. (A) LncRNAs could be precursors of miRNAs. P53 regulated PDL-1 via miR-34, and miR-34 enhanced T cell activation via targeting diacylglycerol kinase $\zeta$. (B) LncRNAs could act as ceRNAs to alter the distribution of miRNA molecules on their targets. 


\section{Ethics approval and consent to participate}

Not applicable.

\section{Abbreviations}

NSCLC: non-small cell lung cancer; lncRNA: long non-coding RNA; SCLC: small cell lung cancer; MALAT1: metastasis-associated lung adenocarcinoma transcript 1; NEAT2: nuclear-enriched abundant transcript 2; EMT: epithelial-mesenchymal transition; AS: alternative splicing; SR: serine/arginine; HOTAIR: HOX antisense intergenic RNA; ceRNA: competing endogenous RNA; HOTTIP: HOXA distal transcript antisense RNA; SBF2-AS1: SBF2 antisense RNA 1; HOXA11-AS: HOXA11 antisense RNA; PCAT-1: Prostate cancer-associated transcript 1; BCAR4: breast cancer anti-estrogen resistance 4; CCAT2: colon cancer-associated transcript 2; XIST: X inactivate-specific transcript; NEAT1: nuclear enriched abundant transcript 1; SNHG1: small nucleolar RNA host gene 1; TUSC7: Tumor suppressor candidate 7; CASC2: cancer susceptibility candidate 2; GAS5: growth arrest-specific transcript 5; UCA1: Urothelial cancer-associated 1; AK126698: IncRNA AK126698; DDR: DNA damage repair; CCAT2: Colon Cancer Associated Transcript 2; EGFR-TKIs: Epidermal growth factor receptor tyrosine kinase inhibitors; EGFR: Epidermal growth factor receptor; MET: Mesenchymalepithelial transition; TCC: transitional cell carcinoma; PFS: progression-free survival; AFAP1-AS1: actin filamentassociated protein 1 antisense RNA; NPC: nasopharyngeal carcinoma; VEGF: Vascular endothelial growth factor; RCT: randomized controlled trials; OS: overall survival.

\section{Author contributions}

Songqing Fan designed and revised the manuscript. Yuting Zhan wrote the manuscript and drew figures. Hongjing Zang collected related papers and created the tables. Juan Feng, Junmi Lu, Lingjiao Chen participated in the design and revise of the review. All the authors read and approved the final version of the review.

\section{ACKNOWLEDGMENTS}

Not applicable.

\section{CONFLICTS OF INTEREST}

The authors declare that they have no competing interests.

\section{FUNDING}

This work was supported by the National Natural Science Foundations of China (No: 81272566; 81472773).

\section{REFERENCES}

1. Siegel RL, Miller KD, Jemal A. Cancer statistics, 2016. CA Cancer J Clin. 2016; 66:7-30.

2. Chen W, Zheng R, Zeng H, Zhang S, He J. Annual report on status of cancer in China, 2011. Chin J Cancer Res. 2015; 27:2-12.

3. Pikin OV, Ryabov AB, Glushko VA, Kolbanov KI, Amiraliev AM, Vursol DA, Bagrov VA, Barmin VV. Surgery for non-small cell lung carcinoma after previous chemoradiotherapy alone. Khirurgiia (Mosk). 2016; 28-31.

4. Shi X, Sun M, Liu H, Yao Y, Song Y. Long non-coding RNAs: a new frontier in the study of human diseases. Cancer Lett. 2013; 339:159-166.

5. Schmitt AM, Chang HY. Long Noncoding RNAs in Cancer Pathways. Cancer Cell. 2016; 29:452-463.

6. Wilusz JE, Sunwoo H, Spector DL. Long noncoding RNAs: functional surprises from the RNA world. Genes Dev. 2009; 23:1494-1504.

7. Ricciuti B, Mencaroni C, Paglialunga L, Paciullo F, Crinò L, Chiari R, Metro G. Long noncoding RNAs: new insights into non-small cell lung cancer biology, diagnosis and therapy. Med Oncol. 2016; 33:18.

8. Ji P, Diederichs S, Wang W, Böing S, Metzger R, Schneider PM, Tidow N, Brandt B, Buerger H, Bulk E, Thomas M, Berdel WE, Serve H, et al. MALAT-1, a novel noncoding RNA, and thymosin beta4 predict metastasis and survival in early-stage non-small cell lung cancer. Oncogene. 2003; 22:8031-8041.

9. Schmidt LH, Spieker T, Koschmieder S, Schäffers S, Humberg J, Jungen D, Bulk E, Hascher A, Wittmer D, Marra A, Hillejan L, Wiebe K, Berdel WE, et al. The long noncoding MALAT-1 RNA indicates a poor prognosis in non-small cell lung cancer and induces migration and tumor growth. J Thorac Oncol. 2011; 6:1984-1992.

10. Zhang CG, Yin DD, Sun SY, Han L. The use of lncRNA analysis for stratification management of prognostic risk in patients with NSCLC. Eur Rev Med Pharmacol Sci. 2017; 21:115-119.

11. Shen L, Chen L, Wang Y, Jiang X, Xia H, Zhuang Z. Long noncoding RNA MALAT1 promotes brain metastasis by inducing epithelial-mesenchymal transition in lung cancer. J Neurooncol. 2015; 121:101-108.

12. Guo F, Guo L, Li Y, Zhou Q, Li Z. MALAT1 is an oncogenic long non-coding RNA associated with tumor invasion in non-small cell lung cancer regulated by DNA methylation. Int J Clin Exp Pathol. 2015; 8:15903-15910.

13. Schmidt LH, Görlich D, Spieker T, Rohde C, Schuler M, Mohr M, Humberg J, Sauer T, Thoenissen NH, Huge A, Voss R, Marra A, Faldum A, et al. Prognostic impact of Bcl2 depends on tumor histology and expression of MALAT-1 lncRNA in non-small-cell lung cancer. J Thorac Oncol. 2014; 9:1294-1304. 
14. Tripathi V, Ellis JD, Shen Z, Song DY, Pan Q, Watt AT, Freier SM, Bennett CF, Sharma A, Bubulya PA, Blencowe BJ, Prasanth SG, Prasanth KV. The nuclear-retained noncoding RNA MALAT1 regulates alternative splicing by modulating SR splicing factor phosphorylation. Mol Cell. 2010; 39:925-938.

15. Gutschner T, Hämmerle M, Diederichs S. MALAT1 -- a paradigm for long noncoding RNA function in cancer. $\mathrm{J}$ Mol Med (Berl). 2013; 91:791-801.

16. Rinn JL, Kertesz M, Wang JK, Squazzo SL, Xu X, Brugmann SA, Goodnough LH, Helms JA, Farnham PJ, Segal E, Chang HY. Functional demarcation of active and silent chromatin domains in human HOX loci by noncoding RNAs. Cell. 2007; 129:1311-1323.

17. Yao Y, Li J, Wang L. Large intervening non-coding RNA HOTAIR is an indicator of poor prognosis and a therapeutic target in human cancers. Int J Mol Sci. 2014; 15:18985-18999.

18. Zhang J, Zhang P, Wang L, Piao HL, Ma L. Long noncoding RNA HOTAIR in carcinogenesis and metastasis. Acta Biochim Biophys Sin (Shanghai). 2014; 46:1-5.

19. Liu XH, Liu ZL, Sun M, Liu J, Wang ZX, De W. The long non-coding RNA HOTAIR indicates a poor prognosis and promotes metastasis in non-small cell lung cancer. BMC Cancer. 2013; 13:464.

20. Nakagawa T, Endo H, Yokoyama M, Abe J, Tamai K, Tanaka N, Sato I, Takahashi S, Kondo T, Satoh K. Large noncoding RNA HOTAIR enhances aggressive biological behavior and is associated with short disease-free survival in human non-small cell lung cancer. Biochem Biophys Res Commun. 2013; 436:319-324.

21. Zhai N, Xia Y, Yin R, Liu J, Gao F. A negative regulation loop of long noncoding RNA HOTAIR and p53 in non-smallcell lung cancer. Onco Targets Ther. 2016; 9:5713-5720.

22. Deng F, Zhou K, Cui W, Liu D, Ma Y. Clinicopathological significance of $\mathrm{wnt} / \beta$-catenin signaling pathway in esophageal squamous cell carcinoma. Int J Clin Exp Pathol. 2015; 8:3045-3053.

23. Hajjari M, Salavaty A. HOTAIR: an oncogenic long noncoding RNA in different cancers. Cancer Biol Med. 2015; 12:1-9.

24. Wang KC, Yang YW, Liu B, Sanyal A, CorcesZimmerman R, Chen Y, Lajoie BR, Protacio A, Flynn RA, Gupta RA, Wysocka J, Lei M, Dekker J, et al. A long noncoding RNA maintains active chromatin to coordinate homeotic gene expression. Nature. 2011; 472:120-124.

25. Burgess DJ. Non-coding RNA: HOTTIP goes the distance. Nat Rev Genet. 2011;12:300.

26. Tsang FH, Au SL, Wei L, Fan DN, Lee JM, Wong CC, $\mathrm{Ng}$ IO, Wong CM. Long non-coding RNA HOTTIP is frequently up-regulated in hepatocellular carcinoma and is targeted by tumour suppressive miR-125b. Liver Int. 2015; 35:1597-1606.

27. Sang Y, Zhou F, Wang D, Bi X, Liu X, Hao Z, Li Q, Zhang W. Up-regulation of long non-coding HOTTIP functions as an oncogene by regulating HOXA13 in non-small cell lung cancer. Am J Transl Res. 2016; 8:2022-2032.

28. Li W, Sun M, Zang C, Ma P, He J, Zhang M, Huang Z, Ding Y, Shu Y. Upregulated long non-coding RNAAGAP2AS1 represses LATS2 and KLF2 expression through interacting with EZH2 and LSD1 in non-small-cell lung cancer cells. Cell Death Dis. 2016; 7:e2225.

29. Ke L, Xu SB, Wang J, Jiang XL, Xu MQ. High expression of long non-coding RNA ATB indicates a poor prognosis and regulates cell proliferation and metastasis in non-small cell lung cancer. Clin Transl Oncol. 2016.

30. Wu J, Wang D. Long noncoding RNA TCF7 promotes invasiveness and self-renewal of human non-small cell lung cancer cells. Hum Cell. 2017; 30:23-29.

31. Lv J, Qiu M, Xia W, Liu C, Xu Y, Wang J, Leng X, Huang S, Zhu R, Zhao M, Ji F, Xu L, Xu K, et al. High expression of long non-coding RNA SBF2-AS1 promotes proliferation in non-small cell lung cancer. J Exp Clin Cancer Res. 2016; 35:75.

32. Rong L, Zhao R, Lu J. Highly expressed long non-coding RNA FOXD2-AS1 promotes non-small cell lung cancer progression via $W n t / \beta$-catenin signaling. Biochem Biophys Res Commun. 2017; 484:586-591.

33. Zhang $\mathrm{Y}$, He RQ, Dang $\mathrm{YW}$, Zhang XL, Wang $\mathrm{X}$, Huang SN, Huang WT, Jiang MT, Gan XN, Xie Y, Li P, Luo DZ, Chen G, et al. Comprehensive analysis of the long noncoding RNA HOXA11-AS gene interaction regulatory network in NSCLC cells. Cancer Cell Int. 2016; 16:89.

34. Zhao B, Hou X, Zhan H. Long non-coding RNA PCAT-1 over-expression promotes proliferation and metastasis in non-small cell lung cancer cells. Int J Clin Exp Med. 2015; 8:18482-18487.

35. Gong J, Zhang H, He L, Wang L, Wang J. Increased Expression of Long Non-Coding RNA BCAR4 Is Predictive of Poor Prognosis in Patients with Non-Small Cell Lung Cancer. Tohoku J Exp Med. 2017; 241:29-34.

36. Zhao Z, Wang J, Wang S, Chang H, Zhang T, Qu J. LncRNA CCAT2 promotes tumorigenesis by overexpressed Pokemon in non-small cell lung cancer. Biomed Pharmacother. 2017; 87:692-697.

37. Sun CC, Li SJ, Li G, Hua RX, Zhou XH, Li DJ. Long Intergenic Noncoding RNA 00511 Acts as an Oncogene in Non-small-cell Lung Cancer by Binding to EZH2 and Suppressing p57. Mol Ther Nucleic Acids. 2016; 5:e385.

38. Fang J, Sun CC, Gong C. Long noncoding RNA XIST acts as an oncogene in non-small cell lung cancer by epigenetically repressing KLF2 expression. Biochem Biophys Res Commun. 2016; 478:811-817.

39. Sun C, Li S, Zhang F, Xi Y, Wang L, Bi Y, Li D. Long non-coding RNA NEAT1 promotes non-small cell lung cancer progression through regulation of miR-377-3p-E2F3 pathway. Oncotarget. 2016; 7:51784-51814. https://doi. org/10.18632/oncotarget.10108.

40. Lu Y, Zhou X, Xu L, Rong C, Shen C, Bian W. Long noncoding RNA ANRIL could be transactivated by c-Myc and promote tumor progression of non-small-cell lung cancer. Onco Targets Ther. 2016; 9:3077-3084. 
41. Tian FM, Meng FQ, Wang XB. Overexpression of longnoncoding RNA ZFAS1 decreases survival in human NSCLC patients. Eur Rev Med Pharmacol Sci. 2016; 20:5126-5131.

42. Cui Y, Zhang F, Zhu C, Geng L, Tian T, Liu H. Upregulated IncRNA SNHG1 contributes to progression of non-small cell lung cancer through inhibition ofmiR-101-3p and activation of Wnt/ $\beta$-catenin signaling pathway. Oncotarget. 2017; 8:17785-17794. https://doi.org/10.18632/oncotarget.14854.

43. Li P, Zhang G, Li J, Yang R, Chen S, Wu S, Zhang F, Bai Y, Zhao H, Wang Y, Dun S, Chen X, Sun Q, et al. Long Noncoding RNA RGMB-AS1 Indicates a Poor Prognosis and Modulates Cell Proliferation, Migration and Invasion in Lung Adenocarcinoma. PLoS One. 2016; 11:e0150790.

44. Wang Z, Jin Y, Ren H, Ma X, Wang B, Wang Y. Downregulation of the long non-coding RNA TUSC7 promotes NSCLC cell proliferation and correlates with poor prognosis. Am J Transl Res. 2016; 8:680-687.

45. He X, Liu Z, Su J, Yang J, Yin D, Han L, De W, Guo R. Low expression of long noncoding RNA CASC2 indicates a poor prognosis and regulates cell proliferation in non-small cell lung cancer. Tumour Biol. 2016; 37:9503-9510.

46. Liang W, Lv T, Shi X, Liu H, Zhu Q, Zeng J, Yang W, Yin J, Song Y. Circulating long noncoding RNA GAS5 is a novel biomarker for the diagnosis of nonsmall cell lung cancer. Medicine (Baltimore). 2016; 95:e4608.

47. Lin PC, Huang HD, Chang CC, Chang YS, Yen JC, Lee CC, Chang WH, Liu TC, Chang JG. Long noncoding RNA TUG1 is downregulated in non-small cell lung cancer and can regulate CELF1 on binding to PRC2. BMC Cancer. 2016; 16:583.

48. Fu X, Li H, Liu C, Hu B, Li T, Wang Y. Long noncoding RNA AK126698 inhibits proliferation and migration of non-small cell lung cancer cells by targeting Frizzled- 8 and suppressing Wnt/ $\beta$-catenin signaling pathway. Onco Targets Ther. 2016; 9:3815-3827.

49. Wu Y, Lyu H, Liu H, Shi X, Song Y, Liu B. Downregulation of the long noncoding RNA GAS5-AS1 contributes to tumor metastasis in non-small cell lung cancer. Sci Rep. 2016; 6:31093.

50. Lord CJ, Ashworth A. The DNA damage response and cancer therapy. Nature. 2012; 481:287-294.

51. Ciccia A, Elledge SJ. The DNA damage response: making it safe to play with knives. Mol Cell. 2010; 40:179-204.

52. Jalal S, Earley JN, Turchi JJ. DNA repair: from genome maintenance to biomarker and therapeutic target. Clin Cancer Res. 2011; 17:6973-6984.

53. Kang J, Demaria S, Formenti S. Current clinical trials testing the combination of immunotherapy with radiotherapy. J Immunother Cancer. 2016; 4:51.

54. Valdes M, Nicholas G, Goss GD, Wheatley-Price P. Chemotherapy in recurrent advanced non-small-cell lung cancer after adjuvant chemotherapy. Curr Oncol. 2016; 23:386-390.
55. Helleday T, Petermann E, Lundin C, Hodgson B, Sharma RA. DNA repair pathways as targets for cancer therapy. Nat Rev Cancer. 2008; 8:193-204.

56. Fuertes MA, Alonso C, Pérez JM. Biochemical modulation of Cisplatin mechanisms of action: enhancement of antitumor activity and circumvention of drug resistance. Chem Rev. 2003; 103:645-662.

57. Xiong Y, Huang BY, Yin JY. Pharmacogenomics of platinum-based chemotherapy in non-small cell lung cancer: focusing on DNA repair systems. Med Oncol. 2017; 34:48.

58. Gong WJ, Yin JY, Li XP, Fang C, Xiao D, Zhang W, Zhou HH, Li X, Liu ZQ. Association of well-characterized lung cancer lncRNA polymorphisms with lung cancer susceptibility and platinum-based chemotherapy response. Tumour Biol. 2016; 37:8349-8358.

59. Hu L, Chen SH, Lv QL, Sun B, Qu Q, Qin CZ, Fan L, Guo Y, Cheng L, Zhou HH. Clinical Significance of Long Non-Coding RNA CASC8 rs10505477 Polymorphism in Lung Cancer Susceptibility, Platinum-Based Chemotherapy Response, and Toxicity. Int J Environ Res Public Health. 2016; 13:E545.

60. Liu MY, Li XQ, Gao TH, Cui Y, Ma N, Zhou Y, Zhang GJ. Elevated HOTAIR expression associated with cisplatin resistance in non-small cell lung cancer patients. J Thorac Dis. 2016; 8:3314-3322.

61. Nishiguchi M, Kikuyama H, Kanazawa T, Tsutsumi A, Kaneko T, Uenishi H,Kawabata Y, Kawashige S, Koh J, Yoneda H. Increases in iPS Transcription Factor (Oct4, Sox2, c-Myc, and Klf4) Gene Expression after Modified Electroconvulsive Therapy. Psychiatry Investig. 2015; 12:532-537.

62. Liu Z, Sun M, Lu K, Liu J, Zhang M, Wu W, De W, Wang Z, Wang $\mathrm{R}$. The long noncoding RNA HOTAIR contributes to cisplatin resistance of human lung adenocarcinoma cells via downregualtion of $\mathrm{p} 21$ (WAF1/CIP1) expression. PLoS One. 2013; 8:e77293.

63. Abbas T, Dutta A. p21 in cancer: intricate networks and multiple activities. Nat Rev Cancer. 2009; 9:400-414.

64. Wang Q, Cheng N, Li X, Pan H, Li C, Ren S, Su C, Cai W, Zhao C, Zhang L, Zhou C. Correlation of long non-coding RNA H19 expression with cisplatin-resistance and clinical outcome in lung adenocarcinoma. Oncotarget. 2017; 8:2558-2567. https://doi.org/10.18632/oncotarget.13708.

65. Li Z, Zhao L, Wang Q. Overexpression of long non-coding RNA HOTTIP increases chemoresistance of osteosarcoma cell by activating the Wnt/ $\beta$-catenin pathway. Am J Transl Res. 2016; 8:2385-2393.

66. Chen H, Xin Y, Zhou L, Huang JM, Tao L, Cheng L, Tian J. Cisplatin and paclitaxel target significant long noncoding RNAs in laryngeal squamous cell carcinoma. Med Oncol. 2014; 31:246.

67. Wang Y, Cheng N, Luo J. Downregulation of lncRNA ANRIL represses tumorigenicity and enhances cisplatininduced cytotoxicity via regulating microRNA let-7a in nasopharyngeal carcinoma. J Biochem Mol Toxicol. 2017. 
68. Yoon SM, Shaikh T, Hallman M. Therapeutic management options for stage III non-small cell lung cancer. World J Clin Oncol. 2017; 8:1-20.

69. Wu AJ, Garay E, Foster A, Hsu M, Zhang Z, Chaft JE, Huang J, Rosenzweig KE, Rimner A. Definitive Radiotherapy for Local Recurrence of NSCLC After Surgery. Clin Lung Cancer. 2017.

70. Youroukou A, Gkiozos I, Kalaitzi Z, Tsalafoutas I, Papalla K, Charpidou A, Kouloulias V. The potential role of brachytherapy in the irradiation of patients with lung cancer: a systematic review. Clin Transl Oncol. 2017.

71. Li L, Zhu T, Gao YF, Zheng W, Wang CJ, Xiao L, Huang MS, Yin JY, Zhou HH, Liu ZQ. Targeting DNA Damage Response in the Radio (Chemo) therapy of NonSmall Cell Lung Cancer. Int J Mol Sci. 2016; 17:E839.

72. Ahmad P, Sana J, Slavik M, Slampa P, Smilek P, Slaby O. MicroRNAs Involvement in Radioresistance of Head and Neck Cancer. Dis Markers. 2017:8245345.

73. Lynch TJ, Bell DW, Sordella R, Gurubhagavatula S, Okimoto RA, Brannigan BW, Harris PL, Haserlat SM, Supko JG, Haluska FG, Louis DN, Christiani DC, Settleman $\mathrm{J}$, et al. Activating mutations in the epidermal growth factor receptor underlying responsiveness of non-small-cell lung cancer to gefitinib. N Engl J Med. 2004; 350:2129-2139.

74. Pao W, Miller V, Zakowski M, Doherty J, Politi K, Sarkaria I, Singh B, Heelan R, Rusch V, Fulton L, Mardis E, Kupfer D, Wilson R, et al. EGF receptor gene mutations are common in lung cancers from "never smokers" and are associated with sensitivity of tumors to gefitinib and erlotinib. Proc Natl Acad Sci USA. 2004; 101:13306-13311.

75. Ohashi K, Maruvka YE, Michor F, Pao W. Epidermal growth factor receptor tyrosine kinase inhibitor-resistant disease. J Clin Oncol. 2013; 31:1070-1080.

76. Hanan EJ, Eigenbrot C, Bryan MC, Burdick DJ, Chan BK, Chen Y, Dotson J, Heald RA, Jackson PS, La H, Lainchbury MD, Malek S, Purkey HE, et al. Discovery of selective and noncovalent diaminopyrimidine-based inhibitors of epidermal growth factor receptor containing the T790M resistance mutation. J Med Chem. 2014; 57:10176-10191.

77. Balak MN, Gong Y, Riely GJ, Somwar R, Li AR, Zakowski MF, Chiang A, Yang G, Ouerfelli O, Kris MG, Ladanyi M, Miller VA, Pao W. Novel D761Y and common secondary T790M mutations in epidermal growth factor receptormutant lung adenocarcinomas with acquired resistance to kinase inhibitors. Clin Cancer Res. 2006; 12:6494-6501.

78. Yamaguchi F, Fukuchi K, Yamazaki Y, Takayasu H, Tazawa S, Tateno H, Kato E, Wakabayashi A, Fujimori M, Iwasaki T, Hayashi M, Tsuchiya Y, Yamashita J, et al. Acquired resistance L747S mutation in an epidermal growth factor receptor-tyrosine kinase inhibitor-naïve patient: A report of three cases. Oncol Lett. 2014; 7:357-360.

79. Goyal S, Jamal S, Shanker A, Grover A. Structural investigations of T854A mutation in EGFR and identification of novel inhibitors using structure activity relationships. BMC Genomics. 2015; 16:S8.
80. Suda K, Mizuuchi H, Maehara Y, Mitsudomi T. Acquired resistance mechanisms to tyrosine kinase inhibitors in lung cancer with activating epidermal growth factor receptor mutation--diversity, ductility, and destiny. Cancer Metastasis Rev. 2012; 31:807-814.

81. Wang XS, Zhang Z, Wang HC, Cai JL, Xu QW, Li MQ, Chen YC, Qian XP, Lu TJ, Yu LZ, Zhang Y, Xin DQ, Na $Y Q$, et al. Rapid identification of UCA1 as a very sensitive and specific unique marker for human bladder carcinoma. Clin Cancer Res. 2006; 12:4851-4858.

82. Hong HH, Hou LK, Pan X, Wu CY, Huang H, Li B, Nie $\mathrm{W}$. Long non-coding RNA UCA1 is a predictive biomarker of cancer. Oncotarget. 2016; 7:44442-44447. https://doi. org/10.18632/oncotarget.10142.

83. Guo S, Yang $\mathrm{P}$, Jiang $\mathrm{X}$, Li X, Wang $\mathrm{Y}$, Zhang $\mathrm{X}$, Sun B, Zhang Y, Jia Y. Genetic and epigenetic silencing of mircoRNA-506-3p enhances COTL1 oncogene expression to foster non-small lung cancer progression. Oncotarget. 2017; 8:644-657. https://doi.org/10.18632/ oncotarget.13501.

84. Cheng N, Cai W, Ren S, Li X, Wang Q, Pan H, Zhao M, Li J, Zhang Y, Zhao C, Chen X, Fei K, Zhou C, et al. Long noncoding RNA UCA1 induces non-T790M acquired resistance to EGFR-TKIs by activating the AKT/mTOR pathway in EGFR-mutant non-small cell lung cancer. Oncotarget. 2015; 6:23582-23593. https://doi.org/10.18632/oncotarget.4361.

85. Cheng N, Li X, Zhao C, Ren S, Chen X, Cai W, Zhao M, Zhang Y, Li J, Wang Q, Zhou C. Microarray expression profile of long non-coding RNAs in EGFR-TKIs resistance of human non-small cell lung cancer. Oncol Rep. 2015; 33:833-839.

86. Pan H, Jiang T, Cheng N, Wang Q, Ren S, Li X, Zhao C, Zhang L, Cai W, Zhou C. Long non-coding RNA BC087858 induces non-T790M mutation acquired resistance to EGFRTKIs by activating PI3K/AKT and MEK/ERK pathways and EMT in non-small-cell lung cancer. Oncotarget. 2016; 7:49948-49960. https://doi.org/10.18632/oncotarget.10521.

87. Ma P, Zhang M, Nie F, Huang Z, He J, Li W, Han L. Transcriptome analysis of EGFR tyrosine kinase inhibitors resistance associated long noncoding RNA in non-small cell lung cancer. Biomed Pharmacother. 2017; 87:20-26.

88. Ni L, Dong C. New checkpoints in cancer immunotherapy. Immunol Rev. 2017; 276:52-65.

89. Nurieva R, Thomas S, Nguyen T, Martin-Orozco N, Wang Y, Kaja MK, Yu XZ, Dong C. T-cell tolerance or function is determined by combinatorial costimulatory signals. EMBO J. 2006; 25:2623-2633.

90. Freeman GJ, Long AJ, Iwai Y, Bourque K, Chernova T, Nishimura H, Fitz LJ,Malenkovich N, Okazaki T, Byrne MC, Horton HF, Fouser L, Carter L, et al. Engagement of the PD-1 immunoinhibitory receptor by a novel B7 family member leads to negative regulation of lymphocyte activation. J Exp Med. 2000; 192:1027-1034.

91. Dong H, Strome SE, Salomao DR, Tamura H, Hirano F, Flies DB, Roche PC, Lu J, Zhu G, Tamada K, Lennon VA, Celis E, Chen L. Tumor-associated B7-H1 promotes T-cell 
apoptosis: a potential mechanism of immune evasion. Nat Med. 2002; 8:793-800.

92. Soo RA, Kim HR, Asuncion BR, Fazreen Z, Omar MF, Herrera MC, Yun Lim JS, Sia G, Soong R, Cho BC. Significance of immune checkpoint proteins in EGFRmutant non-small cell lung cancer. Lung Cancer. 2017; 105:17-22.

93. Daskivich TJ, Belldegrun A. Words of wisdom. Re: Safety, activity, and immune correlates of anti-PD-1 antibody in cancer. Eur Urol. 2015; 67:816-817.

94. Tabchi S, Kourie HR, Kattan J. Adding checkpoint inhibitors to tyrosine kinase inhibitors targeting EGFR/ALK in non-small cell lung cancer: a new therapeutic strategy. Invest New Drugs. 2016; 34:794-796.

95. Ahn MJ, Sun JM, Lee SH, Ahn JS, Park K. EGFR TKI combination with immunotherapy in non-small cell lung cancer. Expert Opin Drug Saf. 2017; 16:465-469.

96. Yin L, Guo H, Zhao L, Wang J. The programmed death-1 gene polymorphism (PD-1.5C/T) is associated with nonsmall cell lung cancer risk in a Chinese Han population. Int J Clin Exp Med. 2014; 7:5832-5836.

97. Tang Y, He Y, Shi L, Yang L, Wang J, Lian Y, Fan C, Zhang P, Guo C, Zhang S, Gong Z, Li X, Xiong F, et al. Co-expression of AFAP1-AS1 and PD-1 predicts poor prognosis in nasopharyngeal carcinoma. Oncotarget. 2017; 8:39001-39011. https://doi.org/10.18632/oncotarget.16545.

98. Cortez MA, Ivan C, Valdecanas D, Wang X, Peltier HJ, Ye Y, Araujo L, Carbone DP, Shilo K, Giri DK, Kelnar K, Martin D, Komaki R, et al. PDL1 Regulation by p53 via miR-34. J Natl Cancer Inst. 2015; 108.

99. Shin J, Xie D, Zhong XP. MicroRNA-34a enhances T cell activation by targeting diacylglycerol kinase $\zeta$. PLoS One. 2013; 8:e77983.

100. Smolle MA, Calin HN, Pichler M, Calin GA. Noncoding RNAs and immune checkpoints-clinical implications as cancer therapeutics. FEBS J. 2017.

101. Cesana M, Cacchiarelli D, Legnini I, Santini T, Sthandier O, Chinappi M, Tramontano A, Bozzoni I. A long noncoding
RNA controls muscle differentiation by functioning as a competing endogenous RNA. Cell. 2011; 147:358-369.

102. Qu L, Ding J, Chen C, Wu ZJ, Liu B, Gao Y, Chen W, Liu F, Sun W, Li XF, Wang X, Wang Y, Xu ZY, et al. ExosomeTransmitted lncARSR Promotes Sunitinib Resistance in Renal Cancer by Acting as a Competing Endogenous RNA. Cancer Cell. 2016; 29:653-668.

103. Kerbel RS. Tumor angiogenesis. N Engl J Med. 2008; 358:2039-2049.

104. Jenab-Wolcott J, Giantonio BJ. Bevacizumab: current indications and future development for management of solid tumors. Expert Opin Biol Ther. 2009; 9:507-517.

105. Eskens FA, Sleijfer S. The use of bevacizumab in colorectal, lung, breast, renal and ovarian cancer: where does it fit? Eur J Cancer. 2008; 44:2350-2356.

106. Roviello G, Bachelot T, Hudis CA, Curigliano G, Reynolds AR, Petrioli R, Generali D. The role of bevacizumab in solid tumours: A literature based meta-analysis of randomised trials. Eur J Cancer. 2017; 75:245-258.

107. Li X, Song Y, Liu F, Liu D, Miao H, Ren J, Xu J, Ding L, Hu Y, Wang Z, Hou Y, Zhao G. Long Non-coding RNA MALAT1 Promotes Proliferation, Angiogenesis and Immunosuppressive Properties of Mesenchymal Stem Cells by Inducing VEGF and IDO. J Cell Biochem. 2017; 118:2780-2791.

108. Castellano JJ, Navarro A, Viñolas N, Marrades RM, Moises J, Cordeiro A, Saco A, Muñoz C, Fuster D, Molins L, Ramirez J, Monzo M. LincRNA-p21 Impacts Prognosis in Resected Non-Small Cell Lung Cancer Patients through Angiogenesis Regulation. J Thorac Oncol. 2016; 11:2173-2182.

109. Peng H, Wang J, Li J, Zhao M, Huang SK, Gu YY, Li Y, Sun XJ, Yang L, Luo Q, Huang CZ. A circulating noncoding RNA panel as an early detection predictor of nonsmall cell lung cancer. Life Sci. 2016; 151:235-242. 